\title{
A century of economics and engineering at Stanford
}

\author{
Beatrice Cherrier \& Aurélien Saïdi
}

CNRS \& THEMA, Université de Cergy; EconomiX, Université Paris Nanterre

\section{Introduction ${ }^{1}$}

In 2018, the prestigious John J. Carty Award for the Advancement of science was, for the first time, awarded to economists. ${ }^{2}$ The laureates, Robert Wilson, David Kreps and Paul Milgrom, came from Stanford University. Together with a fourth colleague, John Roberts, they pioneered "economic engineering," which Kreps describes as "adapt[ing] what is learned from the stylized models and apply them to real-world contexts." Examples range "from auctions of the radio spectrum to models for school choice to kidney exchanges ... licenses for mobile communications and other uses." In a seminal 2002 paper entitled "The Economist as Engineer," Al Roth, a former student of Wilson, further argued that this research program created a shift in economics' identity. He explained that "design economics" exhibited relationships between theory and applications akin to those of physics and engineering:

\begin{abstract}
"[B]ridge design also concerns metallurgy and soil mechanics, and the sideways forces of water and wind ... These complications, and how they interact with the parts of the physics captured by the simple model, are the domain of the engineering literature. Engineering is often less elegant than the simple underlying physics, but it allows bridges designed on the same basic model to be built longer and stronger over time, as the complexities and how to deal with them become better understood."
\end{abstract}

The comparison was not merely metaphorical. Wilson, Kreps and Roth shared a background

\footnotetext{
${ }^{1}$ We are grateful to Pedro Duarte and Yann Giraud, Al Roth, two referees, the participants into the 2018 HOPE conference, as well as Oliver Beige, Philippe Fontaine, David Kreps, Eddie Nik-Khah and Bob Wilson for their very helpful comments. Errors remain our own. We are also indebted to Rebecca Pernell, Paul Reist, and all the librarians, archivists and warehouse workers of the Stanford Libraries and Special Collections for their helpful assistance.

${ }^{2}$ It had been awarded to Elinor Ostrom in 2004. Though she later received the Bank of Sweden economics prize in honor of Alfred Nobel, the Carty award was conferred to her as representing "social/political science."
} 
in Operation Research. ${ }^{3}$ And it was his contributions to this same field that earned famed Stanford theorist Kenneth Arrow the 2014 "Stanford Engineering Hero" prize, alongside Google's Sergueï Brin and Larry Page, and Sally Ride, the first woman to fly in space. Historians of economics (Armatte 2010, Morgan 2003, Klein 2015) have long pointed to some cross-fertilization between economics and engineering, and the purpose of the present volume is to document and characterize it more systematically. Our paper raises the question of the role specific institutions played in nurturing such cross-fertilization, and takes Stanford as a case study.

Previous research has documented diverging intra-university dynamics. At MIT, Paul Samuelson and Robert Solow tapped the administrative requirements that all students receive substantial training in mathematics and physics to support the development of a more formalized "new economics," but the lack of substantial collaboration between economists and engineers in OR or energy pricing is striking (Weintraub 2014, Thomas 2014, Breslau (this volume)). At Carnegie, Judy Klein (2015; this volume) documents remarkable tool transfers, with optimal control and dynamic programming techniques developed for missile guidance finding their way into macroeconomic modeling. Most of the cross-disciplinary ventures examined by historians however took place in extra-university environments (Fontaine 2015). ${ }^{4}$ The Statistical Research Group or the RAND Corporation, among others, cradled decision theory, statistics, linear programming, operations research, system analysis and game theory. ${ }^{5}$ In this respect, the existing literature on Stanford exhibits an interesting gap. Though the university was home to Arrow's contribution to OR and to economic engineering, Stanford is largely overlooked in accounts of Cold War economics or the rise of market design (Mirowski and Nik-Khah 2017). At the same time, economists are altogether absent from the histories of how the RAND, the Cold War military, the Federal government and the rising electronic and computer industry borrowed from and shaped Stanford

\footnotetext{
${ }^{3}$ Giraud and Duarte (this volume) note that $40 \%$ of John Bates Clark laureates can claim some background in engineering.

${ }^{4}$ Fontaine 2015 proposes to use the word 'multidisciplinary' to convey a process where disciplines coexist, 'interdisciplinary' to denote exchanges between disciplines, 'transdisciplinary' to characterize a desire to build a common overarching framework, and 'cross-disciplinary' as a general term without special emphasis on a type and degree of relation between discipline. What we document is the existence of interdisciplinary transfers between economics and engineering. The two communities of scholars did more than just coexist in departments and workshops, but retained some disciplinary identity throughout their work.

${ }^{5}$ See Jardini 1996 and Bessner 2015 on the RAND, Erickson et alii 2013 and Mirowski 2002 on decision science, Erickson 2015 on the history of game theory or Thomas 2015 on the history of operations research.
} 
engineering and fostered the rise of a "Cold War University" (Leslie 1993, Lowen 1997, Gilmore 2004, O’Mara 2019). Our paper attempts to bridge this gap through documenting and explaining a paradox. We argue that though economics was, for a long time, given little attention, esteem and resources by Stanford administrators, Wilson, Milgrom, Kreps and Roth were nevertheless heirs to a century-long intellectual tradition and operated within an institutional structure designed to foster the kind of cross-disciplinary exchanges they built on. Engineers borrowed economists' normative decision tools. Economists retained engineers' mathematical tools and modeling strategies, but also a fine-grained knowledge of production and innovation processes, and ultimately, a "design" epistemology whereby scientific knowledge is shaped by clients' needs, and theoretical and applied work are articulated with the purpose of designing and building (economic) systems that work rather than just modeling them.

We document the key role played by engineers like Herbert Hoover or Frederick Terman in defining the university's strategy, its longstanding intellectual, financial and cultural association with the developing Californian industrial milieu, the ability to attract a flow of scientists for short-term visits and permanent positions. Terman's view of research, in particular, was entrepreneurial and relied on the ability to attract public and private contracts. A consequence was that those economists modeling allocation, decision, production, growth and innovation, later pricing, competition and business strategies with statistics, optimal control or game theory found home at the school of Engineering and the Graduate School of Business (hereafter GSB) more than in the long-neglected Department of Economics.

This paper should neither be read a history of economics, engineering or management science at Stanford and their idiosyncrasies. ${ }^{6}$ None of the research programs or institutional arrangements we described were unique to Stanford. Rather, we document how some of the engineering and economics theories, tools and epistemologies developed elsewhere were recombined in a specific institutional setting and entrepreneurial culture, thus came to infuse to vision that some Stanford economists developed and spread in the last decades.

\footnotetext{
${ }^{6}$ Accordingly, we leave out large chunks of the history of Stanford economics: the rise of macroeconomics and of political economy in the 1980s, the labor economics tradition, the contested influence of the Hoover institution, the type of agricultural, environmental and development economics engineered at the Food Research Institute, or the role of the Center for Advanced Studies in the Behavioral Sciences in fostering the crossfertilization of economics and psychology.
} 


\section{Prologue: economics and engineering in the Wild Wild West}

From Stanford's early days, economics held an ambiguous and paradoxical position. On the one hand, the discipline was not a priority, though a School of Humanities and Social Science was immediately established. It was even regarded with suspicion by trustees and administrators. The university was opened in 1891 by Jane and Leland Stanford, railroad barons, with the purpose of competing with Eastern Universities. ${ }^{7}$ It was built ex nihilo on sunny rural land. A remote area in an already isolated state, Stanford was immediately given a devoted train station. Drawing inspiration from the development of Cornell, the Stanfords ambitioned to retain the scientists and especially engineers meant to foster the economic development of the West in California. Its motto, taken from German, praised the "Wind of Freedom" and embodied an ambitious pioneering spirit whereby frontiers, geographical, social and economic were meant to be pushed. ${ }^{8}$

Not only did the university prioritize engineering training and equipment during its first 50 years of existence, but its strategy, orientations and culture were largely shaped by engineers. After the death of the Stanfords, Herbert Hoover, trained as an in-house geologist at Stanford and a successful mining engineer before being elected president, quickly ascended as the key trustee and donor. He managed to get his friend Ray Wilbur elected as Stanford president and campaigned for the establishment of a graduate school of business, which opened in 1925. It coincided with the recruitment of electrical radio engineer Frederick Terman, trained at MIT by Vannevar Bush. Hoover, Wilbur, Terman, who was soon nominated chairman of the Department of Civil Engineering, general secretary Paul Davis, trustee and future Stanford president Donald Tresidder, all shared a common vision: research was to be developed for and funded by industrial partners. Terman thus encouraged students, among whom William Hewlett, David Packard and the Varian brothers, to set up new firms to develop and commercialize advances in radio engineering, vacuum tubes and circuits, like the klystron tube and the audio oscillator.

None of these key prewar administrators held economics in high esteem, despite the Department of Economics and Sociology housing renowned scholars, including Allyn Young,

\footnotetext{
${ }^{7}$ Leland Stanford presided over the Southern Pacific Railroad and cofounded the Central Pacific. This history of Stanford is largely taken from Leslie 1933, Elliott 1937, and Nash 1988.

8 The university Charter, likewise stated that its goal was to "qualify students for personal success and direct usefulness in life"
} 
Thorstein Veblen, Frank Fetter and Harold Hotelling. None however stayed more than a few years and some resigned amidst controversies. That the first appointed sociologist, Edward A. Ross, attacked railroad patrons (including Stanford himself) for undermining efforts from Chinese workers to unionize did not help. Hoover also resented economists' support for Senator Robert La Folette and their campaign for public management of utilities like railroads and water power. As they would continue to do after World War II, economists also resisted pressures to fund research through industrial and business partnerships, which they believed threatened their independence. Administrators, who rather conceived public funding as threatening, retorted with (aborted) plans to place the Department of Economics within the business school "where its professors might properly focus on issues of concerns to industry" (Lowen 1997, 71). The institutional and intellectual independence of economics within Stanford was thus constantly challenged, a trend that did not abate with the establishment of a standalone Department of Economics in 1948.

At the same time, Stanford engineers insisted that economic and management knowledge were key to sound engineering "design." The first two economics courses offered by the Department of Civil Engineering in 1891 were "Economic Theory of Railroad Location," based on Arthur M. Wellington's 1887 The Economic Theory of the Location of Railroad, and "Railroad operations and Management" (Bulletin 1891/92, 60; 84). Wellington (1887, 1) opened his book with the warning that "engineering ... is rather the art of not constructing ... the art of doing that well with one dollar." The course bulletin described bridge design as "bridge location, economic relation between the cost of superstructure and substructure" (Bulletin 1891/1892, 86) and electrical engineering students were likewise instructed to focus on "the economics, design and management of central station systems" (p. 136).

The set of economic courses for engineers soon became articulated and important enough to be established as an independent curriculum called "Engineering Economy," then a whole "Industrial Engineering" program during the 1930s, and a "Civil Engineering Administration" 2-year graduate curriculum co-operated by the School of Engineering and the GSB. The course offering was developed by John C.L. Fish, author of a 1915 principles book on Engineering Economics. It was then taken over by Eugene Grant, a professor of civil engineering also trained in Economics. Grant was influenced by Fish's idea that "every engineering structure, with few exceptions, is first suggested by economic requirements ... the so-called principles of design are subordinate to the principles which underlie economic 
judgment." (Fish 1915, p. v). He applied the techniques Fish had developed to study railroad to telecommunications. In 1930, Grant published an influential textbook, Principles of Engineering Economy, in which he used cost-benefit analysis to compare business alternatives. It borrowed from cost accounting and finance more than microeconomics.

The war entailed a shift in the university patronage, from industrial clients to the military, but this in fact strengthened the reliance on external funding and the insistence that teaching and research should be oriented toward clients' needs. Efforts to embed the new interdisciplinary War science into a university structure did not raise the status of economics as a discipline within the university, but it created new institutional spaces that nurtured a series of theoretical, epistemological and practical transfers between some economists and engineers.

\section{Nesting the new sciences of decision, allocation and production into engineering (1945-1967)}

\section{Embedding the new Cold War science into a university disciplinary structure}

The war and the ensuing Cold War prompted a massive metamorphosis of all sciences, hard, social and humanities. Historians have extensively documented how the demands for more efficient allocation algorithms, new accounting systems, new decisions rules to produce planes, submarines, to schedule bombing strategies, and to guide missiles were channeled into extra-university entities like the Statistical Research Group (SRG), the RAND corporation (aka the Air force research group), the Office of Naval Research (hereafter ONR) and the Cowles Commission. ${ }^{9}$ This fostered interdisciplinary interactions between mathematicians, physicists, psychologists, economists, etc.

The science they came up with was of quantitative, mathematical and applied nature. Linear programming, statistical decision theory, operations research, optimal control theory, inventory theory, game theory, or sequential analysis, all were born out of the need to deal with pressing practical problems. Mathematician George Dantzig, for instance, was famously asked by the Air Force to organize the airlift of supplies during the 1948-9 Berlin blockade.

\footnotetext{
${ }^{9}$ See note 5, as well as the references in Cravens and Solovey 2012.
} 
Building on Leontief's input-output matrices, he represented the task as a system of a hundred of mutually dependent linear equations to be maximized under a set of inequalities (the practical constraints). The mathematical intractability of the system prompted him to build on the theory of convex sets to forge the simplex algorithm. Likewise, in the summer of 1948 at Santa Monica, Arrow, statistician Abraham Girschik and mathematician David Blackwell pooled together to solve a mathematical problem they had encountered as they worked on inventory decision rules, that is how to balance the costs and benefits of gathering information through sequential testing (Erickson et alii 2013, chapter 2).

Like other universities, in particular nearby Berkeley, Stanford was eager to tap this pool of new methods. The challenge was to convince those scientists used to work into interdisciplinary settings to comply with the more disciplinary structure of the university. A solution was to create new interdisciplinary and application-oriented departments within the stable school structure. One example was the Department of Statistics, founded in 1945 within the School of Humanities. Upon return from Harvard, where he had led the prestigious Radio Research Lab, Terman, now dean of the School of Engineering, applied the contract-capturing and "steeples of excellence" development strategy he had successfully implemented during the war (O'Mara 2019, chapter 2). He helped recruit statistician Al Bowker at the instigation of ONR mathematical division head, Mina Rees. The purpose was to draw funding from the military and lure top scientists into a new research environment. Bowker modeled the new department he headed on SRG, where he had worked with scientists from all disciplines during the war. [We are] "hopefully having a series of problems come in from either government or industry, having enough space so that all of the young scholars, graduate students and the faculty could be housed in the same building, easily accessible to each other," he explained (quoted in Olkin 1987, 473). He recruited Abraham Girshick in 1948, Wald's student Herman Chernoff in 1950, Herbert Scarf in 1957, Herbert Solomon in 1959. Stanford increasingly resembled an annex of the RAND offices in Santa Monica, with an equal number of mathematical economists and statisticians recruited at Berkeley.

Terman and Bowker also relied on joint appointments and shared course sequences to create an environment in which the science military patrons needed could be produced, and to create bridges between schools and departments. Mechanical engineer and former SRG staffer Gerald Lieberman was jointly recruited by the Departments of Statistics and Industrial Engineering, and quickly found himself in charge of the engineering economy and quality 
control courses. Samuel Karlin was recruited in mathematics and statistics, and set to develop courses not just for statisticians, but also for engineers, businessmen, psychologists and economists. In 1957-1958, for instance, he was teaching sampling from human population, statistical methods in engineering and physical sciences, theory of games and statistical decisions, management science and decision theory. Most important, Bowker managed to recruit Arrow from the Cowles Commission on a joint appointment at the Departments of Statistics and Economics. ${ }^{10}$

Arrow's influence in bridging disciplines was enormous. He spent his summers at RAND and later organized workshops with political scientists and philosophers. He contributed to the development of sequential decision with Blackwell and Girshick, optimal inventory policy with Thomas Harris and Jacob Marschak, mathematical modeling of allocation, broadly considered, with Patrick Suppes and Karlin. He applied most of these tools to economic topics - general equilibrium theory, endogenous growth, production. But unlike other contemporary economists covering a wide range of topics and tools (such as Paul Samuelson), he was, by every account, also interested in the institutional architecture of science. He sat on dissertation, departmental, and university committees, chaired research centers. He acted as a major transmission channel between the tools produced by mathematicians and statisticians, the applications promoted by engineers and the knowledge about actual production processes they generated, and the topics favored by economists.

Terman's client-focused strategy was immediately successful. By 1947 already, the School of Engineering was receiving more money from military contracts than from the university itself. An institution builder, he founded the Stanford Research Institute (hereafter SRI) in 1946, a non-profit organization designed to allow commercial contracts too risky for industry and promote science education. He then opened the Electronic Research laboratory and the Stanford Research Park in 1951 to house growing companies funded by former students to commercialize research innovation. His and Bowker's recruits drew millions in small and large grants to the university. For instance, the Varian brothers, Terman's former mentees, offered $\$ 11,000$ to establish a fellowship in economics for students "with engineering or scientific training" (Trustees 1956, 24). Arrow brought a huge ONR contract on the efficiency of decision making from the ONR totaling more than $\$ 200,000$ by 1958 . He

\footnotetext{
10 Arrow was meant to replace Allen Wallis. Part of Arrow's appointment was also at the School of Engineering after it established an OR program in 1962.
} 
also grossed NSF and Rockefeller foundations grants, housed in various programs, department and labs within the university. The contract-focused and entrepreneurial strategy Terman was allowed to spread throughout the university as provost between 1955 and 1965 created space for disciplinary transfers, yet would also further marginalized scholars from the Department of Economics.

\title{
From economists contributing to engineering ...
}

In 1945, Industrial Engineering was formally established as a separate undergraduate program "for students who wish to emphasize the business aspects of engineering" within the department of Civil Engineering (Bulletin 45/46, 257-8). The set of courses offered included Statistics and Accounting for Engineers, Production Engineering, and Machine Design. ${ }^{11}$ By the early 1960s, the Engineering Economy course, now compulsory for industrial engineering undergraduates, was advertised as "economic decision making for engineering alternatives" (Registrar 62/63, 60). The shift highlights the new role the rise of the sciences of decision created for economics, itself in the process of being reframed as the science of rational decision under uncertainty (Erickson et alii 2013, Backhouse and Medema 2009). Beyond Arrow, who initially nurtured those research lines, economists at Stanford as elsewhere collectively understood that rational decision theories was what they had to propose in crossdisciplinary ventures. This was clearly articulated by Stanford econometrician Marc Nerlove in a letter to the chief of the John Hopkins Operations Research Office where he had interned (emphasis added): ${ }^{12}$

\begin{abstract}
"Economics has two general aspects: (1) the first relates to the economy, that is, to a complex of producing, marketing, distributing and consuming institutions and activities. (2) the second relates to economizing, that is, to a certain kind of rational choice and behavior, to making the most of one's resources in achieving one's objectives, in whatever kind of institutional framework. It is the second aspect of economics which I believe especially qualifies economists for work in operation research, for almost all problems of operation research are problems of rational choice in the sense described above."
\end{abstract}

\footnotetext{
11 The program was given its own budget and MS in 1952, under the leadership of William Ireson.

12 Nerlove to Simcox, 04/11/1960, box 146, MNP.
} 
Nerlove's perspective was shared - albeit with a managerial bent - by Alan Manne, who was recruited from Yale at the GSB in 1961 and spent most of his career at Stanford. A former RAND analyst, Manne had just published a textbook entitled Economic Analysis for Business Decisions, which he explicitly located in the tradition developed by Grant. The mix of linear and integer programming, inventory models and sequential decision theory covered in the book could be indifferently called engineering economics, operation research or management science, and reflected the convergence of economic analysts and business executives when it came to analyze "the internal operation of the business enterprise" (Manne 1961, v-vii). In the introduction, he presented a Dantzig transportation problem where the most efficient route between several factories needed to be determined to make the case that the economist should be considered as an efficiency expert "concerned with finding ways to increase the organization's profitability" (Manne 1961, 1-5). Some of the dissertations defended at the School of Engineering in these years were thus clearly economic in their topic, such as Eric Thain's 1968 thesis on "the spatial distribution of public investment in a dual economy," supervised by Arrow, Manne and Cottle.

The above quotes attest that the combination of mathematics, statistics, engineering and economics into a new science of decision (military, business and public) had produced a set of new disciplines sometimes called Operation Research (hereafter OR), sometimes called System Analysis. Though close in their content, mathematical tools and RAND origins, the two research programs and associated communities responded to different client demands and were stabilized in distinct communities (Thomas 2015). OR programs were established throughout the country during the 1950s, in particular within those business schools undergoing a process of scienticization under the patronage of the Ford Foundation (Kurhana 2007, Augier and March 2011). The archetypal example of this transformation was the Carnegie Tech's Graduate School of Industrial Administration, headed by economist Georges Leland Bach, where Herbert Simon, Richard Bellman, Franco Modigliani, John Muth and the likes of Robert Lucas, engineered new models of decision, from bounded rationality to dynamic programming and rational expectations. System analysis grew out of the need to rationalize air warfare analysis, but the willingness to model how much human pilots deviated from rationality during aerial combats led RAND social scientists to focus more on "moral" factors. They strove to apply their "science of warfare" to large-scale policy problems of all 
stripes and soon established a separate society for management science. At the same time, efforts to sell OR to industry clients who had long housed operation engineers resulting in a growing emphasis on its "scientific" aspect, understood as its theoretical foundations. OR morphed into a more abstract discipline.

At Stanford, these two branches of the new science of rational decision making tapping economists' knowledge for engineering and business needs were institutionalized in two separate departments. In 1960, the School of Engineering received \$3.4 millions from the Ford Foundation for the development of programs focused on decision-making in the field of public works engineering, operations research, systems optimization, reliability of engineering systems and components and man-machine systems" (Cottle 2010, slide 29). Arrow pushed for the establishment of an interdepartmental committee on the future of OR, which led to the creation of an inter-school program 1962, turned into a degree-granting department in 1967. Chaired by engineer Gerard Lieberman, its faculty was drawn the Departments of Electrical Engineering (Arthur Kalman, William Linvill), Industrial Engineering (Frederick Hillier, Arthur Vienott), Mathematics (Samuel Karlin), Statistics (Herbert Scarf, Herman Chernoff, Herbert Solomon), Economics (Arrow, Hirofumi Uzawa, Marc Nerlove), and the GSB, where Bach had just been recruited. He shared Terman's clientoriented strategy of selecting a few elite quantitative applied research programs to which researchers from various disciplines contributed. This is what business students needed to be taught, he reflected (Augier and March 2011). ${ }^{13}$

At the same time, a distinct Institute in Engineering-Economic System (hereafter EES) was established, covering close topics: "engineering economy, operation research, system theory and the planning of engineering works" (62/63 registrar). It was chaired by electrical engineer William Linvill, and staffed with another set of researchers drawn from the GBS, civil, electrical and engineering, economics but also the Food Research Institute whose trademark was an interdisciplinary structural and institutional approach to development, and political sciences. Arrow later complained that it was like "having two economic departments, one Keynesian and one anti-Keynesian, which is wrong; they both should be working together" (Arrow 2011, 80). Yet, for EES professor Ronald Howard, there was a clear difference between the two programs: "Our discipline was engineering. Theirs [at OR] was

13 Dantzig himself was poached from UC Berkeley on a joint appointment in operations research and computer science in 1966. 
applied mathematics," he explained (quoted in Garber 2009, 267). According to the 1962 registrar, the goal was to "develop improved ... methodology for decision making in public works." Most EES dissertations emphasized a desire to produce "real-world applications" and were completed in specific firms, in line with the distinctive internship requirement pushed by Linvill. ${ }^{14}$ "A unique feature of the program is the internship, a period of experience in the real world that allows a student to test theory the face of reality . . . [and] formulate meaningful research problems ... Problems of broad scope requiring a system viewpoint and thus suitable for the internship experience are found in large industrial firms, in companies and research groups concerned with the design and operation of civilian and military systems, and in government agencies planning and executing public works and economic development projects," the EES registrar read $(1966 / 1967,124)$.

\section{... to engineers turned economists}

The interaction between economists and engineers described above were largely located within the School of Engineering, yet they also affected the kind of topic and methods pursued at the Department of Economics. Shifts in orientation are visible in the database of economics theses defended at Stanford between 1940 and 1990 that we have assembled. ${ }^{15}$ The dominant characteristic of the 1950s was diversity. Welfare economist Tibor Scitovsky supervised or sat on the committee of 7 dissertations during the 1950s. Other active faculty included Keynesian Lorie Tarshis (5), finance macroeconomist Edward Shaw (4) who trained John Gurley, Arrow (4), and Moses Abramovitz (4), who supervised an engineering dissertation on the political economy of petroleum conservation in Oklahoma. Thomas Marschak and John Harsanyi graduated in these years. Topics ranged from international to labor economics and institutional economic history. 1960s figures show a clear dominance of Arrow, who supervised or sat on the committee of 32 dissertations, vs 15 for Ronald McKinnon and Lorie Tarshis and 14 for Melvin Reder and John Gurley. Some of these were formally defended in the OR department. Arrow supervised technical work on "Simultaneous

\footnotetext{
${ }^{14}$ Yaw Ansu, for instance acknowledged his principal advisor (economist Ronald McKinnon) whose "insistence that [his] work stay in touch with real world economic problems has done much to shape both substance and form of the final product" (Ansu 1984, acknowledgments).

${ }^{15}$ We have reconstructed a database of the Stanford dissertations defended between 1891 and 1990 (including titles, dates and committee members) based on the Stanford archives manuscripts. These volumes have been identified by mean of the SearchWorks catalog, from which we have extracted 457 entries in economics, 523 in operations research or engineering-economic systems and 401 from the GSB.
} 
equations and correlation theory" or "mathematical programming in allocation over time," but also dissertations on trade, migration, health and insurance.

Though topics researched and taught at the department spanned international economics, public finance and taxation, labor economics and economic history and development, the main research program was focused on production and growth. It was carried at the department's Research Center for Growth, opened in 1960 to "consolidate a number of research and training activities in the fields of economic development and comparative economics" (Ballandone 2012, 455). The Center was the offspring of two previous projects: the Stanford Project for Quantitative Research in Economic Development launched around 1954 by faculty members Hollis Chenery, Hendrick Houthakker and Abramovitz, then taken over by Emile Despres, and the Quantitative project on Production Functions, coordinated by Arrow, Chenery, Bagisha Minhas and MIT's Robert Solow. The first of these projects had allowed Chenery, recruited at Stanford in 1953, to study scale economies in specific industries, and he, Arrow and others were looking to draw general laws on the shape of production functions from industry specific processes that could be modeled by power-law distributions. At about that time, Nerlove proposed an early implicit empirical application of duality of production and costs to estimate returns to scale in electricity supply. ${ }^{16}$ All this research was informed by engineering-friendly environment in which it was carried.

Chenery's work on production functions drew on his background as a former petroleum engineer. Author of a 1949 Harvard dissertation, Engineering bases for economic analysis, supervised by Leontief, he meant to bridge the gap between an engineering and an economic conception of the production function: "the essential difference between the engineer and the economist lies in the variables that each uses to describe the process of production," he later reflected. "The inputs into the engineering production function include pumps, pipe, energy sources, and skilled labor ... main outputs are the movement of natural gas over varying distances and at different pressures ... design laws [for pipelines] can be used to construct a production function linking inputs and outputs. The economist's cost function can then be derived by replacing some of the engineering variables with economic variables which

\footnotetext{
${ }^{16}$ Nerlove $(1993,125)$ remembered that when he presented a version of the electricity supply at a seminar, Uzawa said "you can always recover production function from cost function. I thought it was a question, but Uzawa said... 'not a question. Always true."'
} 
conceptualize output as a function of the types of capital goods, labor and raw material," he went on (Chenery, 1992, 373).

The Stanford interdisciplinary institutional setting also allowed the transfer of mathematical tools to economics. The many models of optimal growth written by faculty, including Arrow and Hirofumi Uzawa and graduate students like Menahem Yaari, Karl Shell, David Cass and David Starrett were challenging to solve. Uzawa's two-sector model and Cass's optimum growth model included infinite-horizon maximizing agents and constraints, the kind of problems that are hardly solved with the classical calculus of variations in use in economics since Frank Ramsey. The engineering environment in Stanford provided the adequate generalization of these techniques: it was Karlin who suggested that Uzawa checked Pontryagin's Mathematical Theory of Optimal Processes, just translated into English in 1962. Growth economists tapped engineering knowledge in other ways. In his learning-by-doing paper, Arrow 1962 modeled the learning process by a log-linear equation. He borrowed this idea from research on the learning processes in the airframe industry carried at RAND and the SRI (Ballandonne 2012, 470-72).

The kind of interdisciplinary research drawing hundreds of thousands of dollars from clients Arrow spearheaded was exactly the kind of endeavor favored by Terman, but it remained an exception within the Department of Economics. Only the research in economic development (with a growing industrial focus) and international economics led by Chenery, Houthakker and Tarshis drew an equivalent amount funding from the Ford Foundation (Trustees 1958, 402). The much smaller grants Shaw, Tarshis, Haley, Baran or Abramovitz received from the SSRC, Brookings or the NBER did not convince Stanford administrators to endow the department with more human and space resources, to the growing dismay of economists. After a bitter 1955 battle between Terman and Shaw, then chairman, Arrow had already warned Stanford president Wallace Sterling that it was "a mistake to channel all research into the particular lines for which outside support is available and into relatively large projects . . . the Individual Scholar, working in a field which may or may not be currently fashionable plays a very vital role in economics" (quoted in Lowen 1997, 161). By the mid-1960s, Scarf, Uzawa and Nerlove, having fought with Terman over recruitment, were gone, and emerging stars Zvi Griliches, Franklin Fischer and Dale Jorgenson had turned down offers. Arrow blamed it on the lack of cooperation of the university in opening fullprofessorships and aligning salaries with other universities, warned that such brain drain in 
economic theory reduced Stanford's status in the field considerably. ${ }^{17} \mathrm{He}$ finally left for Harvard in 1967, amidst speculation that he resented the University's lack of support to economics or simply wanted to be closer to policy decision-making circles (see the many interviews in Feiwel 1987).

\section{Crisis and renewal (1967-1990)}

\section{A twofold crisis}

Arrow's departure threw a "demoralized and deteriorating" Department of Economics in disarray, so much so that the associate dean of the School of Humanities and Sciences Richard Lyman appointed a committee in 1971 and invited Nerlove, now at Chicago, to propose a plan for renewal. ${ }^{18}$ His report stressed that Stanford economics suffered from fragmentation. Economists were institutionally and geographically scattered across the university, at the School of Engineering, the School of Medicine, the Food Research Institute, the Center for Advanced Study in the Behavioral Sciences (hereafter CASBS), the Hoover institution, the rising GSB and the Institute for Public Policy. ${ }^{19} \mathrm{He}$ suggested that some unification was in order, that full-professorship be established within the department, that economists be given control over fundraising and appointments of peers across the university (deans were those with the real power), and physically housed in one place.

In response, economists were allowed to grow their faculty to 30, attracting Joseph Stiglitz, Michael Spence, Theodore Anderson, Roger Noll, Robert Hall, etc. and succeeding in getting Arrow back. Yet by the mid-1980s, little had changed. Many of the new recruits only stayed a few years. ${ }^{20}$ In 1985, the faculty sent Nathan Rosenberg, then chairman of the department, a long collective letter titled "The Priority of Economics at Stanford: an urgent need for change." They complained about their lack of attractiveness. Not only did they have

\footnotetext{
${ }^{17}$ Nerlove to Abramovitz, 02/26/1964; Abramovitz to Griliches, undated, folder "Correspondence: Jan 1964March 64," Arrow to Full professors, memorandum, undated ; Arrow to full professors, 06/06/1963, all from box 146, MNP.

${ }_{18}$ See https://news.stanford.edu/news/2005/july13/memlrosse-071305.html

${ }^{19}$ Nerlove to Arrow, 09/20/1973 ; "Innovation and Change in the Social Sciences at Stanford University," Nerlove, undated. Box 5, folder "Marc Nerlove;" KAP.

${ }^{20}$ Spence, for instance, only stayed at the department of economics from 1973-1975. He came back in the 1990s, but at the GSB.
} 
to deal with the "Cambridge Mystique" (East-coast departments were always selected in case of competing job offerings), but as the NSF was widely slashing support to social sciences, business schools were on the rise throughout the country, cannibalizing funding, recruits and students: "the paradoxical outcome is that the same Economics which has been subjected to current political hostility and severe resource cut backs in the School of Humanities and Sciences has been declared desirable by the business community and lavishly endowed with financial support when conducted in a school of business." To compete, they had no building and too little university funding for research, visiting scholars, or yearly seminars, and no computer facility.

The lingering departmental crisis was simmering in the context of a larger social and financial crisis. The late 1960s and 1970s were troubled times at Stanford, as elsewhere. Students' ire targeted the preferred institution whereby military money was channeled into academic research, the Stanford Research Institute (Mody 2017). The Applied Electronics laboratory was occupied and classified research was banned, resulting in a 2 million $\$$ budget shortfall. This prompted a reorientation of Stanford's research toward interdisciplinary problem-solving research related to transportation, urban, population and environmental issues. While economists were not directly targeted by the protests, the ensuing gradual withdrawal of military patrons (including the reorientation of RAND's research agenda toward social and urban studies) affected their research programs. The financial, institutional and intellectual relationships with industrial business clients, while overshadowed by the weight of the military demands of the postwar decades of the 1960s, needed to be reinforced.

\section{The rise of the economist as a market designer}

At the time Stanford economists were searching for a consistent vision, a wealth of new theories, tools and research question were emerging in the profession. None of these were architected at Stanford, but they were brought together through the university's summer workshop tradition, combined by a handful of scholars among whom Robert Wilson, who blended them with an focus on applied theory borrowed from OR and an awareness to business applications characteristic of the GSB, which housed his research group.

In the 1960s, game theory experienced a renewal under the guise of an evolution from its cooperative to its non-cooperative species (Erickson 2015, chapter 7). Thomas Schelling's 
research on armed conflict resolution led John Harsanyi to transform the analysis of games with incomplete information into games with complete but imperfect information. Richard Selten studied what kind of strategies and resulting equilibria emerged from playing such games in dynamic settings. Interest in the consequences of information imperfections and asymmetries on market outcomes was pervasive, with Arrow contributing the foundational paper in the analysis of the health market before leaving to Harvard. Another set of questions came from Minnesota's theorist Leonid Hurwicz, who pointed out the destabilizing effects of information asymmetries. A long-term co-author of Arrow, he began to rethink informational efficiency in resource allocation processes while visiting Stanford in 1958-1959. ${ }^{21}$ In 1973, he suggested that economists should not merely take existing market settings as object of study, but also study which "mechanism" (i.e., which procedure that uses messages received from agents to select an outcome, the decision to produce a public good or a market allocation) was optimal. The challenge was to identify "incentive compatible" mechanisms inducing participants to reveal information about their true beliefs.

These new research orientations launched a race to analyze new types of dynamic games and develop all sorts of equilibrium refinements, with the soon-thwarted hope to identify unique equilibria. While the hothouse of game theory in the 1970s was Northwestern, most of this flourishing literature was brought to Stanford through the large number of visitors who came through the CASBS, and in particular through the summer workshop, organized annually by Mordecai Kurz, at the Institute for Mathematics in the Social Sciences (IMSS) from 1969. Initially funded by the Ford Foundation and later supported by the Hoover institution, this workshop brought together mathematical economists for a 6 to 8 weeks program combining presentation and day-long courses. In 1982, for instance, July workshops were taught by Eric Maskin ("Incentive theory") or Hurwicz and Marschak ("Resource Allocation Mechanism in Discrete spaces"). Rogerson presented on the role of reputation in repeated agency problems, Drew Fudenberg on sequential equilibria, and Roger Myerson on the value of games with incomplete information. ${ }^{22}$

\footnotetext{
${ }^{21}$ His resulting paper was published in 1960 in the book on mathematical models for social sciences edited by Arrow, Karlin and Suppes.

22 The workshop is still active under a new heading, SITE. Another workshop series important in the development of game theory and market design was the Conference on Econometrics and Mathematical Economics (CEME), inaugurated at Berkeley in the early 1970s. It was instigated by Arrow and divided in two branches, general economics and decentralization, first coordinated by Debreu and Radner (then Kreps took over, and by the early 1980s, Wilson and Milgrom were also regular presenters).
} 
Economists then looked for applications beyond international warfare, among whom Robert Wilson. Trained under Howard Raiffa at the Harvard Business School, Wilson had participated into the famous seminar in which Bayesian games were forged. In 1963, he defended a dissertation presenting an algorithm to solve non-linear programming problems before taking a position at the Stanford GSB. Though he "was still considered partly an operations researcher" by the late 1960s and kept training student in that area (Jennergreen 2002,1), he gradually turned to problems of bargaining and auctions. As then explained by Michael Rothkopf (1969, 362), “operations researchers are starting to construct bidding models that are realistic and that consider simultaneously the optimality of the decisions of all bidders." "Only Wilson has begun to take account of the uncertainty of a bidder about the value of the subject of the auction to himself," he continued. Building on Bayesian assumptions on how economic agents use new information to revise their beliefs across time, Wilson modeled a no-regret strategy whereby each agent would use the information revealed by other player's leaving the auction to recalibrate her own reservation value, and studied the resulting bidding equilibrium.

In line with his OR background and the business school environment in which he was operating, Wilson paired his theoretical interests with a distinctive concern for real-world applications. His work on auctions was aimed at providing better strategies to bid for offshore oil tracts to the oil companies he was advising, so as to escape the "winner's curse" - winning as a result of having ex ante overestimated the value of the commodity. ${ }^{23}$ Likewise, his work on the pricing of public utilities, culminating in the publication of the book Nonlinear Pricing in 1983, was fueled by his consulting work for the Analysis Research Group at the Xerox Palo Alto Research Center and for the Electric Power Research Institute. ${ }^{24}$ Applying game theoretic concepts of strategy and equilibrium to real-world situation often meant relaxing informational requirements, dealing with the fact that equilibrium are indeterminate, multiple and very sensitive to players' beliefs, that outcomes can be non budget-balanced and manipulated by coalitions, that the computational burden for solutions is often intractable, and that preparing bids is often extremely costly. Wilson took these constraints into account in his

\footnotetext{
23 The problem had been clearly outlined (and christened) in a seminal 1971 paper by three oil engineers from Atlantic Richfield Co., E.C. Capen, R.V. Clapp and W.M. Campbell.

${ }^{24}$ Former Stanford PhD student Samuel Oren, a Xerox staffer, remembers that in 1979, "we became interested in broadband communication [...] there were no customers, so how do you do market research? [...] Wilson introduced us to the whole area of non-linear pricing, market design." See also Rothkopf (2000).
} 
theoretical work. In the end, his economics, though building upon game theoretic rather than financial accounting, programming or optimal control tools, was in the spirit of the work of the likes of Grant and Manne: it was knowledge built with the purpose of making practical industrial management decisions more efficient. ${ }^{25}$

This blend of theoretical rigor and practical bent Wilson imparted on the stream of students he directed, as well as those many more who attended, often several years in a row, his graduate lectures. The graduate students he trained in the 1970s and early 1980s included Roth, Milgrom, Holmström, Armando Ortega-Reichert, Claude d'Aspremont and Peter Cramton. Many of them shared an OR background with Wilson, and several built on prior professional experience as they entered the graduate program. Milgrom had worked as an actuary, and Holmström had worked as an OR analyst at a Finnish conglomerate. "My interest in incentives had been raised by the problems I had encountered when trying to implement a large-scale corporate planning model at Ahlstrom," he later explained (Holmström 2002, 1). Many of them were trained within a newly founded "Decision Sciences Group" founded by Wilson and a cluster of researchers interested in OR, applied mathematics and economics at the GSB. ${ }^{26}$

It was within the GSB, the summer workshops organized by the IMSS and other newly established interdisciplinary spaces that the moribund tradition of introducing students to game theory's applications was gradually renewed. While Karlin had published a two volume book on Mathematical methods and Theory in Games, Programming and Economics in 1959 , by the late 1960 s, the topic was not taught anymore. It was (re)taught by IMSS visitors like Aumann (courses offered in 1971 and 1975), as well as Michael Maschler (1973). In his business course "Competitive Strategies," based on business case, Wilson suggested students read references by Dresher, Luce and Raiffa, Von Neumann and Morgenstern,

\footnotetext{
${ }^{25}$ In the introductory essay to a tribute volume, Milgrom, Holmström and Roth $(2002,1)$ pointed to Wilson's emphasis that "the value of theory is its usefulness in addressing practical problems," which Roth (2018) called "the Wilson Doctrine." Mirowksi and Nik-Khah (2017) claim that it was only the "experimental school" of market design led by Roth which "designed" markets, and that the two previous schools, Hurwicz's "walrasian school" and Wilson's "bayesian school" remained highly theoretical. What we argue here is that, though theoretical, Wilson's approach was applied in that it was aimed at solving business clients' issues, therefore already a "design" practice akin to what engineers were doing.

26 They included OR specialist Evan Porteus, who was working on Markov decision processes, and later his student David Kreps, who had completed a dissertation in the theory of dynamic programming . In the 1970s, the GSB was organized into "groups" including the Economic Policy Analysis Group run by GSB's Bach, Accounting, Finance, Marketing and Organizational Behavior. It was a structure more fluid and less hierarchical than a departmental one, and facilitated interdisciplinary transfers (Wilson, correspondence with authors).
} 
Shubik, Aumann, Cottle, Dantzig and Karlin. ${ }^{27}$ He then set up a course on "multi-person decision theory," in which he was teaching the modeling strategy and key results of the 16 papers from the previous year that he had found most noteworthy.

As hinted above, the operationalization of Hurwicz's hope to "design" markets required permanent trade-offs between theoretical purity, information requirements, concepts of equilibria, the legal and institutional characteristics of the real-world, and the computational abilities of real players and the scientists who advised them. The development of experimental economics (see Svorencik 2016) afforded new ways for testing auction and matching designs. Architected at Arizona State, Caltech and other experimental economic labs, these techniques were brought to Stanford through, again, the creation of new workshops. Upon moving back to California in 1979, Arrow, whose interest in decision theory and applied and interdisciplinary bent had not abated, organized an interdisciplinary seminar in applied decision analysis with Wilson, Amos Tversky from the Department of Psychology, and organization theorist James March. It was advertised as the "study of normative and descriptive decision making particularly in the face of uncertainty ... problems arising in making decisions analyses in applied policy contexts" (Registrar 1980-1981, 341), and featured Vernon Smith on risk aversion auction, as well as Charles Plott, Richard Thaler, and political scientists and law scholars. In subsequent years, presentations focused on conflict and negotiations. ${ }^{28}$ As highlighted in our introduction, Roth largely contributed to blend game theoretic tools, experiments and a concern for design he had inherited from his engineering background and continued discussions with his wife Emily Roth, a psychologist specialized in cognitive engineering (Roth and Wilson 2018).

What emerged from this outline is not just a two-way street between economics and engineering, but a three-legged nexus of engineering, economics and management, each discipline growing closer to the other two. When Milgrom was brought back to Stanford in the early 1980s, Arrow pointed out that "in the field of managerial economics (the common part of decision analysis and microeconomic theory), it is hard to find anyone common with him." At the same time, Industrial administration $\mathrm{PhD}$ and marketing professor Seenu

\footnotetext{
27 "Lectures on Cooperative Game Theory," Aumann, July 1971; "Analysis of Competitive Strategies" Wilson, Spring 1973, all Box 21, ARP. In his syllabus, Wilson noted the lack of treatment of uncertainty and applications to "the practical context of managerial decisions."

${ }^{28}$ Arrow came back to Stanford with a ONR grant to establish a "Center on Decision and Conflict in Complex Organizations," for which he got a grant from the Hewlett foundation in 1988. He also participated in the development of a program in political economy.
} 
Srinivanan was setting up a GSB joint course on the design of new product with Operational Management professor William Lovejoy and mechanical engineer David Beach. Called "Integrated Design for Marketability and Manufacturing," it illustrated the complementarities of engineering and business. One knew "how to understand consumers and how to market a product," the second "how to manufacture" and the third "how to design." The course combined two MBAs and two engineers in each team (Srinivasan 2017).

\section{Rethinking innovation and operations managements}

The overhaul of industrial relations by game theorists and the nascent field of market design were not the only spaces where yet other types of interactions between economics and engineering flourished. Though still centered on decision theory, OR and EES's course offerings evolved with the pressing issues of the time. EES advertised its expertise in the "economics of depletable resources; impact of government policies on economic growth . . . econometrics with particular emphasis on passenger car use of gasoline." Course programs in health policy and energy modeling and analysis were set up (Bulletin 1981-82). In OR too, environment had become a major topic, as a new optimization system lab promised to help students "learn about modeling complex systems dealing with energy, the economy, water." Arrow taught a "theory of information and organization course" throughout the 1980s and 1990s, and OR students were also allowed to attend the conflict resolution seminar, a course on welfare economics by Starrett, or another interdisciplinary seminar in risk management organized by Arrow and Lieberman (Bulletin 1990-1991, 216).

Beginning in the 1970s, interactions between economics and engineering were not merely largely mediated and unified by management (both the client-oriented approach and the GSB flexible group structure), but also increasingly by computer science. In the 1950s, Terman, Bowker, mathematicians and engineers had established a Computation Center and a graduate program in data processing and scientific computation, and recruited George Foresythe to head a small group within the department of mathematics (Cottle 2010). By the late-1960s, it has evolved into an independent Department within the School of Humanities with a strong interdisciplinary bent. Several economists including Manne and Wilson were associated with some of its projects in mathematical programming languages. By the mid- 
1980s, computer science had become so central that it was seen as a basis on which to merge the still independents Departements of OR, EES and Industrial Engineering. In 1985, a failed proposal to establish a joint research center in decision analysis suggested to merge "elements from the social (people, organizations), analytic (logic, mathematics), and technological (enabling technologies) domains to develop and explore new concepts that will be relevant in solving the complex problems of modern businesses and industries. Jim March saw these domains as analogous (sic) to empires competing for power and the center enabling them to make trade agreements." The report pointed out that "a theme emerged based on the idea that it is tough to manage companies and this management can be made easier with computers." The term 'Intelligent Management Systems' was thus chosen as the rallying idea to "express ties to both engineering and business. ${ }^{, 29}$

At the Department of Economics, a distinct "economics of industry" program was taking shape, one that was also influenced by proximity with engineering. It also dealt with health, environment, and market structures, but it was of a more institutional nature. Roger Noll, Tim Bresnahan and others wanted to study oligopoly and the antitrust status of joint ventures, contracts negotiations and property rights in collaboration with the GSB and political scientists, through a detailed study of actual institutional arrangements. Under the leadership of economic historian Paul David and Nathan Rosenberg, economists' traditional concern with the explanation of growth had morphed into a "new economics of science" that drew on case studies to understand the production and dissemination of knowledge and the determinants of innovation (David and Dasgupta 1994).

David had been teaching a course on the determinants and consequences of the diffusion of technological innovations in the economic history of the West from the 9th to the 19th centuries. The key takeaway was the notion of "innovation clusters." His research combined economic theory, history and microeconometrics to analyze technological change, studying the failure of innovation like the reaper to disseminate, on the establishment of standards like the QWERTY keyboard. Rosenberg was teaching a course on "technology and modern industrial society," studying the "socio-economic processes" influencing the rate and direction of technological changes. Some of his knowledge was taken from a seminar on "Science, Technology and Society" organized by an aeronautics engineer, Walter Vincenti

\footnotetext{
29 "Engineering research center proposal 1985" folder, box 66, KAP.
} 
(see Rosenberg and Vincenti 1978). ${ }^{30}$ The latter published an influential 1990 book entitled What Engineers Know and How they Know it. It used examples from the history of aeronautical engineering to construct an epistemology of engineering and to sketch a model of how new technologies are produced. The gist of the argument was to explain what engineers do when they "design" - design variation is affected by "blindness" and selection by "unsureness," so engineers are left combining theoretical knowledge and trials and errors in various ways. Market designers would not have rejected that characterization.

\section{Epilogue}

In the past two decades, the Stanford Department of Economics has eventually managed to rank within the US top-10 departments. The much-covered 1994 FCC auctions for radio spectrum acted as a test for market designer's epistemology of applied economics, and the Stanford economists involved in the process subsequently founded Market Design Inc. ${ }^{31}$ The OR, EES and industrial engineering departments were eventually merged into a new "Management Science and Engineering" department, covering decision analysis and risk analysis, economics and finance, information science and technology, production and operations management, and system modeling and optimization.

The continuing intellectual cross-fertilization and joint institutional redevelopment in economics, engineering, business and more recently computer science, illustrate the paradoxical history of economics at Stanford in the past hundred years. On the one hand, this history was one of a long protracted battle between economists and an administrative hierarchy they felt neglected them, to strengthen their disciplinary boundaries, emphasize their specificities, and get control over funding and recruitment. At the same time, what was crucial to the import of mathematical tools, an engineering perspective on innovation and a "philosophy of design" into economics, and to the export of economists' contributions to the postwar science of decision and allocation to OR and EES was the constant institutional innovations whereby these disciplines were combined and recombined. This involved a long

\footnotetext{
${ }^{30}$ Rosenberg and Vincenti 1978 coauthored book on The Generation and Diffusion of Technological Knowledge. David and Vincenti appear to have read each other's course material, though the extent of their exchanges and mutual influences will be studied from archives in the future. In the 1980s, Rosenberg and David Landau chaired a workshop on technological innovation sponsored by the Department of Economics and the Center for Economic Policy Research.

${ }^{31}$ For historical and methodological analyses of the auctions, see the references listed in Mirowski and NikKhah 2017.
} 
tradition of supporting joint appointments, and of constantly updating a rich and complex network of interschool and interdisciplinary training "programs" and yearly and summer workshops.

In the end, none of the ingredients that shaped the relationships between economics and engineering were specific to Stanford (except the weather), from the rise of statistics and OR to the Cold War context and associated stream of military and federal financial support. If what later came to be called the Silicon Valley formed a unique intellectual and industrial environment, a university forging ties with its industrial milieu was nothing original. Nor was retaining the best students as educators, researchers or business partners. Yet these ingredients were stirred by a few scientists with an interdisciplinary bent like Bowker, Foresythe, Arrow or Wilson as well as engineers turned administrators like Hoover and Terman, who upheld a strong vision of which grants and contracts-capturing research programs should be prioritized. They created an institutional structure in which theoretical, tool and epistemological crossfertilization between disciplines and between researchers, public and business clients was nurtured on a long-term scale. This included interdisciplinary programs like OR, teams at the GBS, and other extra-departmental structures like the Stanford Research Park for electrical engineering and computer science, or the IMSS workshop for mathematical science. Though economics was not a priority in itself, the skills developed by some economists in the context of the Cold War allowed them to become central resources in engineering education and research fostered by the Army, then the large-utilities energy industry, then the Silicon Valley companies. 


\section{References}

KAP: Kenneth Arrow Papers, Duke University

MNP: Marc Nerlove Papers, Duke University

ALP : Al Roth Papers, Duke University

ECON: Department of Economics Papers, Stanford University

Ansu, Yaw, 1984. Monetary and Exchange Rate Policies for an Economy with Parallel Markets: The Case of Ghana, Department of EES, Stanford University

Armatte, Michel. 2010. La Science économique comme ingénierie . Paris: Presses des Mines

Arrow, K. 2011. "Oral History Interview conducted by Jane Hibbard." Stanford Oral History program.

Augier, M. March, J. 2011. The Roots, Rituals, and Rhetorics of Change: North American business schools after Second World War. Stanford, CA : Stanford Business Books

Backhouse, Roger. Medema, Steven. 2009. "On the Definition of Economics" Journal of Economic Perspectives 23(1).

Ballandonne. M. 2012. "New Economics of science, economics of scientific knowledge and sociology of science: the case of Paul David." Journal of Economic Methodology 19(4), 391-406

Ballandonne, M. 2015. Creating Increasing Returns: The Genesis of Arrow's "Learning by Doing." History of Political Economy, 47(3), 448-479

Bessner, 2015. "Organizing Complexity: the Hopeful Dreams and Harsh Realities of Interdisciplinary Collaboration at the RAND Corporation in the Early Cold War." Journal of the History of the Behavioral Sciences 51(1), 31-53.

Chenery, H. 1992. "From Engineering to Economics" BNL Quaterly Review, 183.

Cottle.R. 2010. "The building of Management Science and Engineering at Stanford" powerpoint. Link

Cravens, H. Solovey, M. 2012. Cold War Social Science Knowledge Production, Liberal Democracy, and Human Nature. Palgrave Macmillan

David, P. Dasgupta, 1994. “Toward a new economics of Science," Research Policy 23: 487-532

Elliott, Orrin Leslie, 1937. Stanford University: The First Twenty-Five Years. Stanford University Press.

Erickson, P. 2015. The World the Game Theorists Made. Chicago: The University of Chicago Press

Erickson, P. Klein, J. Daston, L. Lemov, R. Sturm T., Gordin M. 2013. How Reason Almost Lost its Mind: The Strange Career of Cold War Rationality. Chicago: University of Chicago Press

Feiwel, G. (ed.), 1987. Arrow and the Foundations of the Theory of Economic Policy. Palgrave Macmillan 
Fish, John C. 1915. Engineering Economics: First Principles. Mc Graw Hill

Fontaine, 2015. "Introduction: The Social Sciences in a Cross-Disciplinary Age." Journal of the History of the Behavioral Sciences 51(1), 1-9

Garber, Russ. 2009. “An Interview with Ronald A. Howard.” Decision Analysis 6(4):263-272

Gilmore, G. Steward, 2004. Fred Terman at Stanford: Building a Discipline, a University and Silicon Valley. Stanford University Press : Stanford.

Grant, Eugene. [1930] 1938. Principles of Engineering Economy with Problems. New York: Ronald Press Company, p. vii

Holmstrom, B. Milgrom, P. Roth A. 2002. Game Theory in the Tradition of Bob Wilson. https://services.bepress.com/wilson/

Jardini, 1996. Out Of the Blue Yonder: The RAND Corporation's Diversification into ocial Welfare Research: 1946-1968, doctoral dissertation, Carnegie Mellon University

Jennergren, L. Peter, 2002. "Introducton to a Paper Inspired by Bob Wilson, Well-known Optimization Theorist." Game Theory in the Tradition of Bob Wilson 7. https://services.bepress.com/wilson/art7

Khurana, R. 2007. From Higher Aims to Hired Hands The Social Transformation of American Business Schools and the Unfulfilled Promise of Management as a Profession. Princeton University press.

Klein, J. 2015. "The Cold War Hot House for Modeling Strategies at the Carnegie Institute of Technology," INET WP series $n^{\circ} 19$

Leslie, Stuart W. 1993. The Cold War and American Science: The Military-Industrial-Academic Complex at MIT and Stanford. New York: Columbia University Press

Lowen, Rebecca S. 1997. Creating the Cold War University: The Transformation of Stanford; University of California Press.

Manne, 1961. Economic Analysis for Business Decisions. New York: McGraw-Hill

Holmstrom, Bengt; Milgrom, Paul; and Roth, Alvin E. 2002. "Introduction." Game Theory in the Tradition of Bob Wilson. 1.

https://services.bepress.com/wilson/art1

Holmstrom, Bengt, 2002. "Introductory Essay to Groves Scheme on Restricted Domains." Game Theory in the Tradition of Bob Wilson. 19. https://services.bepress.com/wilson/art19

Mirowski, P. 2002. Machine Dreams: Economics Becomes a Cyborg Science. Cambridge: Cambridge Universiy Press

Mirowski, P. Nik-Khah, 2017. "The Knowledge we have lost in information." Oxford: Oxford University Press

Mody, C. 2017. "INterdisciplinarity at Vietnam-Era Stanford" in Frickel et alii (eds) Investigatng Interdisciplinary Collaboration;. New Brunswick: Rutgers University press

Morgan, Mary S. 2003. "Economics." In Porter, Theodore M. and Ross, Dorothy (eds.), The 
Cambridge History of Science Volume 7: The Modern Social Sciences. Cambridge: Cambridge University Press, 275-305.

Nash, Georges H. 1988. Herbert Hoover and Stanford University. Stanford : Hoover Institution.

Nerlove, M. 1993. “The ET Interview by Eric Ghysels,” Econometric Theory 9, 117-143

Olkin, 1987. “A Conversation with Albert H. Bowker.” Statistical Science 2(4), 472-483

O’Mara, M. 2019. The Code: Silicon Valley and the Remaking of America. New York: Penguin.

Rosenberg, N. Vincenti, W. 1978. The Britannia Bridge: The Generation and Diffusion of Technological Knowledge

Roth, Alvin E. 2002. "The Economist as Engineer: Game Theory, Experimentation, and Computation as Tools for Design Economics." Econometrica , 70 (4): 1341-78.

Roth, A. Wilson, R. 2019. "How market design emerged from game theory," Journal of Economic Perspectives 33(3), 118-143

Rothkopft, 1969. “A Model of Rational Competitive Bidding."Management Science 15(7): 362- 373.

Srinivasan, V. Seenu, 2017. “Interview by Leigh McAlister, October 24, 2017," working paper

Svorencik, 2016. The Experimental Turn in Economics, dissertation, Utrecht University.

Thomas, W. 2014. "Decisions and Dynamics: Postwar Theoretical Problems and the MIT Style of Economics," History of Political Economy 46 (suppl_1): 295-314

Thomas, W. 2015. Rational Action: The Sciences of Policy in Britain and America, 1940-1960. MIT University Press

Vincenti, W.G.. 1990. What Engineers Know and How they Know It: Analytical Studies from Aeronautical History. Baltimore: Johns Hopkins University Press.

Weintraub, R. (ed). 2014. "MIT and the Transformation of American Economics" History of Political Economy 46 (suppl_1) 